Article

\title{
Effect of Culture Conditions on Metabolite Production of Xylaria sp.
}

\author{
Hongqi Zhang ${ }^{1}$, Zhangshuang Deng ${ }^{1, *}$, Zhiyong Guo ${ }^{1}$, Yan Peng ${ }^{2}$, Nianyu Huang ${ }^{1}$, \\ Haibo He ${ }^{1}$, Xuan Tu ${ }^{1}$ and Kun Zou ${ }^{1, *}$
}

1 Hubei Key Laboratory of Natural Products Research and Development, College of Biological and Pharmaceutical Sciences, China Three Gorges University, Yichang 443002, China;

E-Mails: zhq6396549@163.com (H.Z.); zhiyongguoctgu@hotmail.com (Z.G.); hny115@126.com (N.H.); haibohe2001@gmail.com (H.H.); tuxuan7@126.com (X.T.)

2 The First College of Clinical Medical Science, China Three Gorges University, Yichang 443002, China; E-Mail: ycpy0303@126.com

* Authors to whom correspondence should be addressed;

E-Mails: d.zhangshuang@gmail.com (Z.D.); kzou@ctgu.edu.cn (K.Z.);

Tel./Fax: +86-717-639-7478 (Z.D. \& K.Z.).

Academic Editor: Derek J. McPhee

Received: 10 March 2015 / Accepted: 28 April 2015 / Published: 30 April 2015

\begin{abstract}
Seeking a strategy for triggering the cryptic natural product biosynthesis to yield novel compounds in the plant-associated fungus Xylaria sp., the effect of culture conditions on metabolite production was investigated. A shift in the production of five known cytochalasin-type analogues 1-5 to six new $\alpha$-pyrone derivatives, xylapyrones $\mathrm{A}-\mathrm{F}$ (compounds 6-11), from a solid to a liquid medium was observed. These compounds were identified by analysis of 1D and 2D NMR and HRMS data. Compounds 1-3 showed moderate cytotoxicity against HepG2 and Caski cancer cell lines with $\mathrm{IC}_{50}$ values ranging from 25 to $63 \mu \mathrm{M}$ and compounds 4-11 were found to be inactive, with $\mathrm{IC}_{50}$ values $>100 \mu \mathrm{M}$.
\end{abstract}

Keywords: Xylaria sp.; cryptic natural product; cytochalasin; $\alpha$-pyrone; xylapyrones; cytotoxicity 


\section{Introduction}

Natural products from microorganisms are a vital source for innovative therapeutic agents and drug leads [1]. Unfortunately, the high rediscovery rate of known compounds in traditional screening methods has completely frustrated researchers [2]. Secondary metabolism of microbes is regulated by large amounts of genes encoding biosynthetic enzymes and therefore a variety of secondary metabolites should be produced [3,4]. In fact, only a minority of pathway genes is expressed under standardized laboratory conditions and many valuable compounds are overlooked. In order to exploit the full metabolic potential of microorganisms, many regulatory strategies to activate cryptic pathways to facilitate the discovery of new natural products through modification of culture conditions [5], external cues [6], stress [7], co-cultures [8] and genomic approaches [9] were described in the literature. In our approach, by altering easily accessible culture conditions from a solid to a liquid medium, a shift in the production of reported cytochalasin-type analogues 1-5 to hitherto unknown $\alpha$-pyrone derivatives 6-11 was observed in the plant-associated fungus Xylaria sp. This paper describes the isolation, structure elucidation, and cytotoxic activities of the isolated compounds 1-11 (Figure 1).

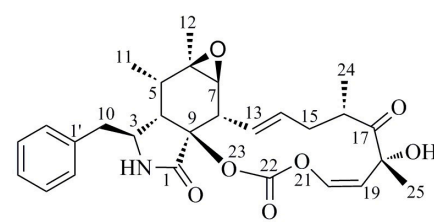

1

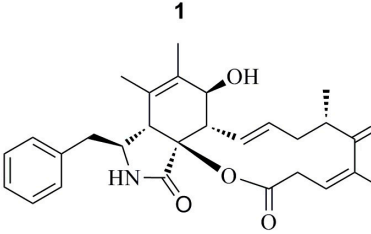<smiles>COc1cc(CCCCO)oc(=O)c1</smiles>

10

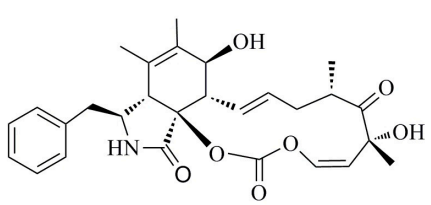

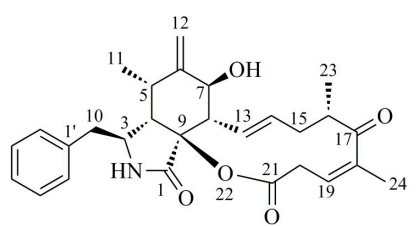

3

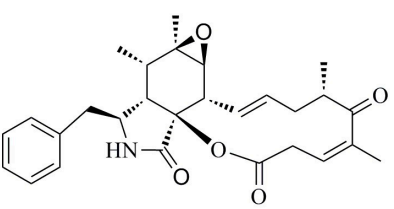

4<smiles>COc1cc(CCCCCO)cc(OC)c1</smiles><smiles>COc1cc(CCCO)oc(=O)c1</smiles>

11

Figure 1. Structures of compounds 1-11.

\section{Results and Discussion}

\subsection{Structure Determination}

The known compounds cytochalasin E (1), cytochalasin K (2), cytochalasin Z16 (3), rosellichalasin (4) and cytochalasin Z17 (5) were identified by comparison of the corresponding ${ }^{1} \mathrm{H}$ - and ${ }^{13} \mathrm{C}-\mathrm{NMR}$ data with published results [10-12].

Compound $\mathbf{6}$ was obtained as a white amorphous powder. The molecular formula was determined to be $\mathrm{C}_{13} \mathrm{H}_{18} \mathrm{O}_{5}$ by HREIMS, implying five degrees of unsaturation. Inspection of the ${ }^{1} \mathrm{H}$-NMR spectrum (Table 1 and Supporting Information) reveals signals for two meta-coupled aromatic protons at $\delta_{\mathrm{H}} 6.91$ and 5.96, three protons at $\delta_{\mathrm{H}} 3.88(3 \mathrm{H}, \mathrm{s})$, one oxygenated methine proton at $\delta_{\mathrm{H}} 3.56$, one methylene proton at $\delta_{\mathrm{H}} 2.85$, three methylene proton in the higher field at $\delta_{\mathrm{H}} 1.54(\mathrm{~m}, 2 \mathrm{H}), 1.35(\mathrm{~m}, 2 \mathrm{H})$ and 1.28 
$(\mathrm{m}, 2 \mathrm{H})$, and one exchangeable proton at $\delta_{\mathrm{H}} 4.32$. The ${ }^{13} \mathrm{C}-\mathrm{NMR}$ and DEPT spectra (Table 1 and Supporting Information) displayed two carbonyl carbons at $\delta \mathrm{c} 193.0$ and 161.6, two olefinic methine carbons at $\delta_{\mathrm{C}} 104.6$ and 93.5 , two $\mathrm{sp}^{2}$ quaternary carbon at $\delta_{\mathrm{C}} 169.5$ and 153.9 , a methoxy carbon at $\delta \mathrm{C}$ 56.9 , an oxygenated methine carbon at $\delta_{c} 65.6$, four methylene carbons at $\delta_{c} 38.7,37.2,24.7$ and 23.0, and a methyl carbon at $\delta_{c}$ 23.6. The $\alpha$-pyrone ring was elucidated as 4-methoxy-2-one with a substitutent at C-6 by analysis of HMBC correlations between $\mathrm{H}_{1}-3\left(\delta_{\mathrm{H}} 5.96\right) / \mathrm{C}-2\left(\delta_{\mathrm{C}} 161.6\right), \mathrm{C}-4\left(\delta_{\mathrm{C}}\right.$ $169.5), \mathrm{C}-5\left(\delta_{\mathrm{C}} 104.6\right), \mathrm{H}_{1}-5\left(\delta_{\mathrm{H}} 6.91\right) / \mathrm{C}-3\left(\delta_{\mathrm{C}} 93.5\right), \mathrm{C}-4\left(\delta_{\mathrm{C}} 169.5\right), \mathrm{C}-6\left(\delta_{\mathrm{C}} 153.9\right)$, and $\mathrm{H}_{3}-\mathrm{OCH}_{3}\left(\delta_{\mathrm{H}}\right.$ $3.88) / \mathrm{C}-4\left(\delta_{\mathrm{C}} 169.5\right)$ (Figure 2). COSY correlations (Figure 2$)$ from $\mathrm{H}_{3}-13\left(\delta_{\mathrm{H}} 1.03\right), \mathrm{OH}-12\left(\delta_{\mathrm{H}} 4.32\right)$ via $\mathrm{H}_{1}-12\left(\delta_{\mathrm{H}} 3.56\right), \mathrm{H}_{2}-11\left(\delta_{\mathrm{H}} 1.35\right), \mathrm{H}_{2}-10\left(\delta_{\mathrm{H}} 1.28\right)$ and $\mathrm{H}_{2}-9\left(\delta_{\mathrm{H}} 1.54\right)$ to $\mathrm{H}_{2}-8\left(\delta_{\mathrm{H}} 2.85\right)$ show the presence of a 2-hexanol group, which is attached to a carbonyl group as indicated by HMBC correlations from $\mathrm{H}_{2}-9\left(\delta_{\mathrm{H}} 1.54\right)$ and $\mathrm{H}_{2}-8\left(\delta_{\mathrm{H}} 2.85\right)$ to $\mathrm{C}-7\left(\delta_{\mathrm{C}} 193.0\right)$, while $\mathrm{H}_{1}-5\left(\delta_{\mathrm{H}} 6.91\right)$ give HMBC correlations (Figure 2$)$ to $C-7\left(\delta_{C} 193.0\right)$ implying that C-7 $\left(\delta_{C} 193.0\right)$ is attached to C-6 $\left(\delta_{C}\right.$ 153.9). The structure of compound $\mathbf{6}$ was therefore determined to correspond to the previously unreported compound 4-methoxy-6-(6-hydroxy-1-oxoheptyl)-2H-pyran-2-one, named xylapyrone A.

Table 1. ${ }^{1} \mathrm{H}$ - and ${ }^{13} \mathrm{C}-\mathrm{NMR}$ spectral data (400 MHz, DMSO) of compounds 6-8.

\begin{tabular}{|c|c|c|c|c|c|c|}
\hline \multirow{2}{*}{ Position } & \multicolumn{2}{|l|}{6} & \multicolumn{2}{|l|}{7} & \multicolumn{2}{|l|}{8} \\
\hline & $\delta_{\mathrm{H}}$ (mult., $J$ in Hz) & $\delta \mathrm{C}$ (mult.) & $\delta_{H}$ (mult., $J$ in $\left.\mathrm{Hz}\right)$ & $\delta \mathrm{c}$ (mult.) & $\delta_{\mathrm{H}}($ mult., $J$ in $\mathrm{Hz})$ & $\delta_{\mathrm{C}}$ (mult.) \\
\hline 2 & & 161.6, qC & & $163.3, \mathrm{qC}$ & & 164.1, qC \\
\hline 3 & $5.96, \mathrm{~d}(2.0)$ & $93.5, \mathrm{CH}$ & $5.54, \mathrm{~d}(2.2)$ & $87.5, \mathrm{CH}$ & $5.52, \mathrm{~d}(2.2)$ & $87.7, \mathrm{CH}$ \\
\hline 4 & & $169.5, \mathrm{qC}$ & & $171.0, \mathrm{qC}$ & & $171.5, \mathrm{qC}$ \\
\hline 5 & $6.91, \mathrm{~d}(2.0)$ & 104.6, CH & $6.10, \mathrm{~d}(2.2)$ & $97.7, \mathrm{CH}$ & $6.05, \mathrm{~d}(2.2)$ & $99.9, \mathrm{CH}$ \\
\hline 6 & & $153.9, \mathrm{qC}$ & & $167.8, \mathrm{qC}$ & & 166.0, qC \\
\hline 7 & & 193.0, qC & $4.22, \mathrm{dt}(5.0,7.6)$ & $68.9, \mathrm{CH}$ & $2.44, \mathrm{t}(7.5)$ & $33.1, \mathrm{CH}_{2}$ \\
\hline 8 & $2.85, \mathrm{t}(7.2)$ & $37.2, \mathrm{CH}_{2}$ & $1.64, \mathrm{~m} / 1.53, \mathrm{~m}$ & $34.7, \mathrm{CH}_{2}$ & $1.55, \mathrm{dt}(7.5)$ & 26.6, $\mathrm{CH}_{2}$ \\
\hline 9 & $1.54, \mathrm{~m}$ & $23.0, \mathrm{CH}_{2}$ & $1.30, \mathrm{~m}$ & $25.1, \mathrm{CH}_{2}$ & $1.30, \mathrm{~m}$ & 25.3, $\mathrm{CH}_{2}$ \\
\hline 10 & $1.28, \mathrm{~m}$ & $24.7, \mathrm{CH}_{2}$ & $1.30, \mathrm{~m}$ & 24.7, $\mathrm{CH}_{2}$ & $1.42, \mathrm{~m}$ & $32.6, \mathrm{CH}_{2}$ \\
\hline 11 & $1.35, \mathrm{~m}$ & $38.7, \mathrm{CH}_{2}$ & $1.30, \mathrm{~m}$ & $38.9, \mathrm{CH}_{2}$ & $3.38, \mathrm{dd}(6.4,11.5)$ & $61.0, \mathrm{CH}_{2}$ \\
\hline 12 & $3.56, \mathrm{~m}$ & $65.6, \mathrm{CH}$ & $3.54, \mathrm{~m}$ & $65.6, \mathrm{CH}$ & & \\
\hline 13 & $1.03, \mathrm{~d}(6.1)$ & 23.6, $\mathrm{CH}_{3}$ & $1.01, \mathrm{~d}(6.2)$ & 23.6, $\mathrm{CH}_{3}$ & & \\
\hline $4-\mathrm{OCH}_{3}$ & $3.88, \mathrm{~s}$ & $56.9, \mathrm{CH}_{3}$ & $3.81, \mathrm{~s}$ & $56.3, \mathrm{CH}_{3}$ & $3.79, \mathrm{~s}$ & 56.7, $\mathrm{CH}_{3}$ \\
\hline $12-\mathrm{OH}$ & $4.32, \mathrm{~d}(4.9)$ & & $4.29, \mathrm{~d}(5.0)$ & & & \\
\hline $7-\mathrm{OH}$ & & & $5.58, \mathrm{~d}(5.4)$ & & & \\
\hline $11-\mathrm{OH}$ & & & & & $4.36, \mathrm{t}(5.1)$ & \\
\hline
\end{tabular}

Compound 7 was also obtained as a white amorphous powder and the molecular formula was deduced to be $\mathrm{C}_{13} \mathrm{H}_{20} \mathrm{O}_{5}$ from the molecular ion peak at $m / z 256.1308[\mathrm{M}]^{+}$(calcd for 256.1311) in the HREIMS, having two more hydrogen atoms than 6. Detailed NMR spectra (Table 1 and Supporting Information) revealed the existence of the same 4-methoxy- $\alpha$-pyrone framework as in 6 and that a carbonyl group in $\mathbf{6}$ has been reduced to a hydroxyl group in 7. The carbonyl group resonating at $\delta \mathrm{C}$ 193.0 (C-7) in the NMR spectra of 6 was absent in those of 7, and instead an oxygenated methine signal at $\delta_{\mathrm{H}} 4.22\left(\mathrm{H}_{1}-7\right)$ and $\delta_{\mathrm{C}} 68.9(\mathrm{C}-7)$ were observed in 7. These observations suggested the hydroxylation at C-7 and this was verified by the HMBC correlations from $\mathrm{H}_{1}-7\left(\delta_{\mathrm{H}} 4.22\right)$ to C-5 ( $\delta_{\mathrm{C}}$ 
97.7), C-6 ( $\left.\delta_{\mathrm{C}} 167.8\right), \mathrm{C}-8\left(\delta_{\mathrm{C}} 34.7\right)$ and C-9 ( $\left.\delta_{\mathrm{c}} 25.1\right)$ (Figure 2). Thus, the structure of 7 was determined to be as shown in Figure 1, and the compound was named xylapyrone B.

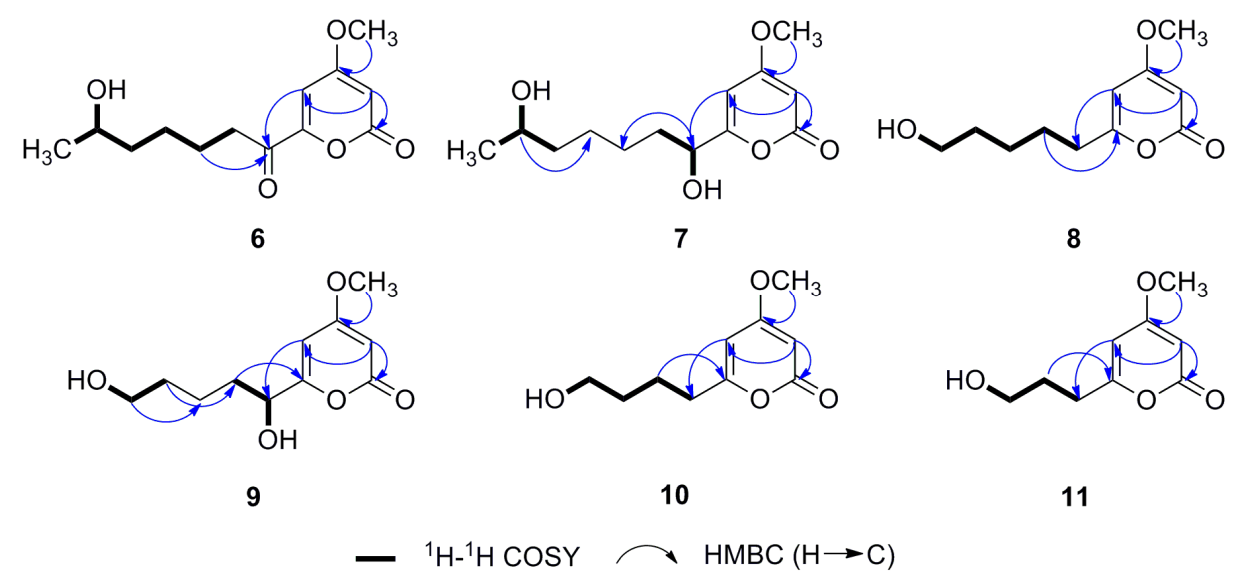

Figure 2. Key HMBC and COSY correlations of compounds 6-11 in DMSO.

Compound 8 has the molecular formula $\mathrm{C}_{11} \mathrm{H}_{16} \mathrm{O}_{4}$ suggested by HREIMS data. ${ }^{1} \mathrm{H}$ - and ${ }^{13} \mathrm{C}-\mathrm{NMR}$ data (Table 1 and Supporting Information) showed that 8 had the same basic 4-methoxy-a-pyrone structure with a substituent at C-6, as 6 and 7. Five methylenes at $\delta_{\mathrm{H}} 3.38, \delta_{\mathrm{H}} 2.44, \delta_{\mathrm{H}} 1.55, \delta_{\mathrm{H}} 1.42(2 \mathrm{H}$, $\mathrm{m})$ and $\delta_{\mathrm{H}} 1.30(2 \mathrm{H}, \mathrm{m})$ were observed in the ${ }^{1} \mathrm{H}-\mathrm{NMR}$ spectra. The corresponding carbon signals at $\delta_{\mathrm{C}}$ 61.0, 33.1, 26.6, 32.6 and 25.3 were present in the ${ }^{13} \mathrm{C}-\mathrm{NMR}$ spectra. The COSY correlations (Figure 2) of five methylenes suggested the side chain was pentanol. Therefore, the structure of xylapyrone $\mathrm{C}$ was unambiguously elucidated as $\mathbf{8}$.

Compound 9 was obtained as a white amorphous solid. Its HREIMS exhibits a peak at $\mathrm{m} / \mathrm{z}$ 228.0991 [M] $]^{+}$(calcd for 228.0998), indicating a molecular formula $\mathrm{C}_{11} \mathrm{H}_{16} \mathrm{O}_{5}$ with one more oxygen atom than $8\left[\mathrm{C}_{11} \mathrm{H}_{16} \mathrm{O}_{4}\right]$. The NMR spectroscopic data (Table 2 and Supporting Information) indicated that they were structurally related, and that they differed in their oxidation status. Detailed analysis of the ${ }^{1} \mathrm{H}$ - and ${ }^{13} \mathrm{C}$-NMR spectra revealed that the methylene unit at $\delta_{\mathrm{H}} 2.44$ and $\delta_{\mathrm{C}} 33.1\left(\mathrm{CH}_{2}\right)$ of 8 was replaced by an oxygenated methine unit at $\delta_{\mathrm{H}} 4.23(1 \mathrm{H}, \mathrm{brs})$ and $\delta_{\mathrm{C}} 69.5(\mathrm{CH})$ in 9 . Unexpectedly, no HMBC correlation from $\mathrm{H}_{1-7}\left(\delta_{\mathrm{H}} 4.23\right)$ to any other carbon signal was observed, so the location of the hydroxyl group was deduced to be $\mathrm{C}-7$ according to the COSY correlations from $\mathrm{OH}-7\left(\delta_{\mathrm{H}} 5.60\right)$ via $\mathrm{H}_{1}-7\left(\delta_{\mathrm{H}} 4.23\right)$ to $\mathrm{H}_{2}-8\left(\delta_{\mathrm{H}} 1.65\right.$ and 1.54$)$ and a strong $\mathrm{HMBC}$ correlation from $\mathrm{H}_{2}-8\left(\delta_{\mathrm{H}} 1.54\right)$ to $\mathrm{C}-6$ $\left(\delta_{\mathrm{C}} 168.3\right)$ (Figure 2$)$. Consequently, the structure of 9 was identified as shown in Figure 1 and named xylapyrone D.

The structures of xylapyrone E (10) and xylapyrone F (11) were determined straightforwardly as they were very similar to those of $\mathbf{8}$. Their NMR data (Table 2 and Supporting Information) and HREIMS suggested the difference of their structures is that side-chains attached to C-6 in $\mathbf{8 , 1 0}$ and $\mathbf{1 1}$ are pentanol, butanol and propanol, respectively. 
Table 2. ${ }^{1} \mathrm{H}$ - and ${ }^{13} \mathrm{C}-\mathrm{NMR}$ spectral data (400 MHz, DMSO-d6) of compounds 9-11.

\begin{tabular}{|c|c|c|c|c|c|c|}
\hline \multirow{2}{*}{ Position } & \multicolumn{2}{|l|}{9} & \multicolumn{2}{|l|}{10} & \multicolumn{2}{|l|}{11} \\
\hline & $\delta_{\mathrm{H}}$ (mult., $J$ in $\mathrm{Hz}$ ) & $\delta_{C}$ (mult.) & $\delta_{H}($ mult., $J$ in $\mathrm{Hz})$ & $\delta_{C}$ (mult.) & $\delta_{\mathrm{H}}($ mult., $J$ in $\mathrm{Hz})$ & $\delta_{C}$ (mult.) \\
\hline 2 & & $163.8, \mathrm{qC}$ & & 164.2, qC & & 164.1, qC \\
\hline 3 & $5.55, \mathrm{~d}(2.0)$ & $88.1, \mathrm{CH}$ & $5.53, \mathrm{~d}(2.2)$ & $87.7, \mathrm{CH}$ & $5.52, \mathrm{~d}(2.2)$ & 87.7, $\mathrm{CH}$ \\
\hline 4 & & $171.5, \mathrm{qC}$ & & $171.5, \mathrm{qC}$ & & $171.5, \mathrm{qC}$ \\
\hline 5 & $6.11, \mathrm{~d}(2.0)$ & $98.3, \mathrm{CH}$ & $6.06, \mathrm{~d}(2.2)$ & $99.9, \mathrm{CH}$ & $6.04, \mathrm{~d}(2.2)$ & $99.8, \mathrm{CH}$ \\
\hline 6 & & $168.3, \mathrm{qC}$ & & 166.0, qC & & $166.0, \mathrm{qC}$ \\
\hline 7 & 4.23 , brs & $69.5, \mathrm{CH}$ & $2.46, \mathrm{t}(7.4)$ & $32.9, \mathrm{CH}_{2}$ & $2.48, \mathrm{t}(7.8)$ & $30.0, \mathrm{CH}_{2}$ \\
\hline 8 & $1.65, \mathrm{~m} / 1.54, \mathrm{~m}$ & $35.0, \mathrm{CH}_{2}$ & $1.60, \mathrm{~m}$ & 23.3, $\mathrm{CH}_{2}$ & $1.70, \mathrm{~m}$ & $30.0, \mathrm{CH}_{2}$ \\
\hline 9 & $1.34, \mathrm{~m}$ & 21.7, $\mathrm{CH}_{2}$ & $1.45, \mathrm{~m}$ & $32.1, \mathrm{CH}_{2}$ & $3.42, \mathrm{dd}(6.0,11.0)$ & $60.1, \mathrm{CH}_{2}$ \\
\hline 10 & $1.40, \mathrm{~m}$ & $32.8, \mathrm{CH}_{2}$ & $3.42, \mathrm{dd}(6.0,11.0)$ & $60.7, \mathrm{CH}_{2}$ & & \\
\hline 11 & $3.37, \mathrm{dd}(6.0,11.1)$ & 61.1, $\mathrm{CH}_{2}$ & & & & \\
\hline \multicolumn{7}{|l|}{12} \\
\hline \multicolumn{7}{|l|}{13} \\
\hline $4-\mathrm{OCH}_{3}$ & $3.81, \mathrm{~s}$ & $56.8, \mathrm{CH}_{3}$ & $3.81, \mathrm{~s}$ & $56.7, \mathrm{CH}_{3}$ & $3.79, \mathrm{~s}$ & $56.7, \mathrm{CH}_{3}$ \\
\hline $7-\mathrm{OH}$ & 5.60, brs & & & & & \\
\hline $11-\mathrm{OH}$ & $4.35, \mathrm{t}(5.0)$ & & & & & \\
\hline $10-\mathrm{OH}$ & & & $4.43, \mathrm{t}(5.0)$ & & & \\
\hline 9-OH & & & & & $4.55, \mathrm{t}(5.0)$ & \\
\hline
\end{tabular}

\subsection{Cytotoxic Properties}

Isolated compounds 1-11 were evaluated for in vitro cytotoxicity against two cancer cell lines HepG2 and Caski. Mitomycin was employed as positive control. Of the tested compounds, compounds 1-3 showed moderate cytotoxicity, with $\mathrm{IC}_{50}$ values ranging from 25 to $63 \mu \mathrm{M}$, and compounds 4-11 were found to be inactive, with $\mathrm{IC}_{50}$ values $>100 \mu \mathrm{M}$ (Table 3). The most cytotoxic compound is cytochalasin E (1). Cytochalasin-type compounds have been reported as promising lead compounds for anticancer drug discovery that reduce the proliferation of different cancer cell lines such as P388, A549 and KB cells [10,11]. $\alpha$-Pyrone natural products are widespread in Nature and have a broad spectrum of biological activities [13]. The literature [14-16] has suggested that structural variations of the side chains attached to $\alpha$-pyrones ring may make significant differences to the cytotoxicity, which is worth further investigation.

Table 3. Cytotoxicities of compounds $\mathbf{1}-\mathbf{1 1}$ against two cancer cell lines ${ }^{\mathrm{a}}$.

\begin{tabular}{cccccccccccc}
\hline & $\mathbf{1}$ & $\mathbf{2}$ & $\mathbf{3}$ & $\mathbf{4}$ & $\mathbf{5}$ & $\mathbf{6}$ & $\mathbf{7}$ & $\mathbf{8}$ & $\mathbf{9}$ & $\mathbf{1 0}$ & $\mathbf{1 1}$ \\
\hline HepG2 & 25 & 59 & 45 & $>100$ & $>100$ & $>100$ & $>100$ & $>100$ & $>100$ & $>100$ & $>100$ \\
Caski & 29 & 63 & 53 & $>100$ & $>100$ & $>100$ & $>100$ & $>100$ & $>100$ & $>100$ & $>100$ \\
\hline
\end{tabular}

${ }^{a}$ Results are expressed as $\mathrm{IC}_{50}$ values in $\mu \mathrm{M}$. An average value of three independent experiments is reported. Hep-G2 and Caski are human liver cancer cell line and human cervical cancer cell line, respectively. 


\section{Experimental Section}

\subsection{General Experimental Procedures}

NMR spectra $\left({ }^{1} \mathrm{H}\right.$ at $400 \mathrm{MHz},{ }^{13} \mathrm{C}$ at $\left.100 \mathrm{MHz}\right)$ were measured on a Bruker Ultrashield TM Plus $400 \mathrm{MHz}$ spectrometer (Faellanden, Switzerland) with tetramethylsilane as an internal standard and chemical shifts were recorded as $\delta$ values. EI and HREIMS spectra were recorded on DSQ II (Thermo Fisher Scientific Inc., Waltham, MA, USA) and MAT95XP (Thermo Electron Corp., Madison, WI, USA) mass spectrometers, respectively. Semipreparative HPLC was performed on a Dionex Ultimate 3000 system (Thermo Fisher Scientific Inc.) using a semipreparative C18 (COSMOSIL $5 \mu \mathrm{m}$, $10 \mathrm{~mm} \times 250 \mathrm{~mm}$ ) column coupled with an diode-array detector. TLC was performed on precoated silica gel GF254 (Merck, Darmstadt, Germany) plates (PTLC, Merck). Silica gel (200-300 mesh) for column chromatography was produced by Qingdao Marine Chemical Factory (Qingdao, China). Sephadex LH-20 was produced by Pharmacia Biotech (Uppsala, Sweden). UV spectra were taken on a UV-3100PC spectrometer (Hitachi, Ltd., Tokyo, Japan).

\subsection{Isolation and Identification of the Strain}

The endophytic fungus Xylaria sp. BM9 was isolated from a piece of fresh tissue from the inner part of a medicinal plant leaf of Saccharum arundinaceum Retz., collected from the Yichang (Hubei Province, China) in April 2011. The fungus was deposited as Xylaria sp. BM9 (GenBank accession numbers KC184129) at the Hubei Key Laboratory of Natural Products Research and Development, College of Chemistry and Life Sciences, China Three Gorges University, Yichang, China.

\subsection{Seed and Mass Cultures of the Strain}

The fungus Xylaria sp. BM9 was maintained on potato dextrose agar. Agar plugs containing the fungal strain were inoculated in $500 \mathrm{~mL}$ Erlenmeyer flasks, each containing $200 \mathrm{~mL}$ of potato dextrose broth. Flask cultures were incubated at $28^{\circ} \mathrm{C}$ on a rotary shaker at $130 \mathrm{rpm}$ for 3 days as seed culture.

Liquid fermentation was performed by the following procedure: each of the seed cultures $(200 \mathrm{~mL})$ was transferred into $500 \mathrm{~mL}$ Erlenmeyer flasks containing $200 \mathrm{~mL}$ of potato dextrose broth. These flasks were incubated at $28{ }^{\circ} \mathrm{C}$ on a rotary shaker at $130 \mathrm{rpm}$ for 14 days. After fermentation, the culture $(25 \mathrm{~L})$ was centrifuged to yield the supernatant and a mycelial cake. The supernatant was extracted three times with an equal volume of EtOAc, the extracts were combined and solvent was removed under reduced pressure. The mycelial cake was immersed in $2 \mathrm{~L}$ of acetone and the organic layers were collected and removed under reduced pressure. Two residues were combined for purification.

Solid fermentation was carried out in $500 \mathrm{~mL}$ Erlenmeyer flasks containing $40 \mathrm{~g}$ rice, each flask was inoculated with the seed cultures $(5.0 \mathrm{~mL})$ and incubated at $25{ }^{\circ} \mathrm{C}$ for 30 days. The fermented material was soaked in EtOAc, and the organic solvent was evaporated to dryness under vacuum to afford the crude extract. 


\subsection{Extraction and Isolation of Compounds}

The liquid fermentation residue (4.0 g) was chromatographed on a silica gel (200-300 mesh) column and eluted with petroleum ether-acetone (1:0, 9:1, 4:1, 2:1, 1:1, and 1:2, v/v) to yield six fractions (Fr. 1-Fr. 6). Fr. 3 (1.2 g) was further separated by semi-preparative reversed-phase HPLC on an ODS semi-preparative C18 column (COSMOSIL $5 \mu \mathrm{m}, 10 \mathrm{~mm} \times 250 \mathrm{~mm}$ ) eluted with $30 \%$ $\mathrm{MeCN} / \mathrm{H}_{2} \mathrm{O}$ to afford 6 (2.8 mg), 7 (5.4 mg), 8 (3.2 mg), 9 (1.5 mg), 10 (4.9 mg) and 11 (1.9 mg).

The solid fermentation residue (50 g) was chromatographed on a silica gel (200-300 mesh) column and eluted with petroleum ether-acetone $(1: 0,9: 1,4: 1,2: 1,1: 1$, and 1:2, v/v) to yield nine fractions (Fr.1-Fr.9). Fr.2 (2.5 g) was further separated by chromatography on a Sephadex LH-20 column eluted with $\mathrm{CHCl}_{3}-\mathrm{MeOH}(\mathrm{v} / \mathrm{v}=1 / 1)$ to yield seven fractions (Fr. 2.1-Fr. 2.7). Fr. 2.3 (200 mg) was further separated by semi-preparative reversed-phase HPLC on an ODS semi-preparative C18 column (COSMOSIL $5 \mu \mathrm{m}, 10 \mathrm{~mm} \times 250 \mathrm{~mm}$ ) eluted with $75 \% \mathrm{MeCN} / \mathrm{H}_{2} \mathrm{O}$ to afford $3(11.3 \mathrm{mg}), 4$ (12.9 $\mathrm{mg})$ and $5(14.6 \mathrm{mg})$. Fr. $2.5(200 \mathrm{mg})$ was successively subjected to semi-preparative reversed-phase $\mathrm{HPLC}$ eluted with $85 \% \mathrm{MeCN} / \mathrm{H}_{2} \mathrm{O}$ to afford $2(1.9 \mathrm{mg})$. The Fr. 4 (1.8 g) was purified by column chromatography over Sephadex LH-20 using an equal ratio mixture of methanol and chloroform as eluent to give $\mathbf{1}(40 \mathrm{mg})$.

Cytochalasin E (1): colorless needles; $\mathrm{C}_{28} \mathrm{H}_{33} \mathrm{NO}_{7}$; UV (MeOH) $\lambda_{\max }(\log \varepsilon) 224$ (2.78), 258 (2.46) nm; ${ }^{13} \mathrm{C}-\mathrm{NMR}$ (acetone-d6): $\delta 212.9$ (C-17), 170.3 (C-1), 150.1 (C-22), 142.4 (C-20), 137.4 (C-1'), 132.1 (C-14), 131.1 (C-2' \& 6'), 129.5 (C-13), 129.1 (C-3' \& 5'), 127.4 (C-4'), 121.7 (C-19), 87.8 (C-9), 77.6 (C-18), 61.2 (C-7), 57.7 (C-6), 53.6 (C-3), 47.5 (C-4), 47.0 (C-8), 44.5 (C-10), 41.1 (C-16), 40.0 (C-15), 36.9 (C-5), 25.0 (C-25), 20.4 (C-24), 19.6 (C-12), 13.1 (C-11); ESIMS m/z 518 [M+Na] , $1013[2 \mathrm{M}+\mathrm{Na}]^{+}$.

Cytochalasin K (2): White amorphous solid; $\mathrm{C}_{28} \mathrm{H}_{33} \mathrm{NO}_{7} ; \mathrm{UV}(\mathrm{MeOH}) \lambda_{\max }(\log \varepsilon) 224$ (3.38), 258 (2.42) nm; ${ }^{13} \mathrm{C}-\mathrm{NMR}\left(\mathrm{CDCl}_{3}\right): \delta 211.5$ (C-17), 170.0 (C-1), 149.0 (C-22), 142.5 (C-20), 136.7 (C-1'), 133.6 (C-14), 131.8 (C-6), 129.4 (C-13), 129.3 (C-2' \& 6'), 129.0 (C-3' \& 5'), 127.2 (C-4'), 125.3 (C-5), 120.5 (C-19), 86.2 (C-9), 77.2 (C-18), 70.1 (C-7), 59.0 (C-3), 50.0 (C-8), 48.4 (C-4), 44.2 (C-10), 41.0 (C-16), 39.0 (C-15), 24.6 (C-25), 20.2 (C-24), 17.7 (C-11), 14.0 (C-12); ESIMS m/z 518 [M+Na], $1013[2 \mathrm{M}+\mathrm{Na}]^{+}$.

Cytochalasin Z16 (3): White amorphous solid; $\mathrm{C}_{28} \mathrm{H}_{33} \mathrm{NO}_{5}$; UV (MeOH) $\lambda_{\max }(\log \varepsilon) 244$ (3.73) nm; ${ }^{13} \mathrm{C}-\mathrm{NMR}\left(\mathrm{CDCl}_{3}\right): \delta 206.1$ (C-17), 171.3 (C-1), 170.0 (C-21), 149.1 (C-6), 143.7 (C-18), 138.1 (C-1'), 137.9 (C-14), 132.9 (C-19), 130.2 (C-2' \& 6'), 129.8 (C-3' \& 5'), 128.0 (C-4'), 126.6 (C-13), 115.8 (C-12), 84.1 (C-9), 69.9 (C-7), 54.4 (C-3), 50.8 (C-8), 49.9 (C-4), 44.6 (C-10), 40.6 (C-15), 40.3 (C-16), 37.2 (C-20), 32.7 (C-5), 18.5 (C-23), 15.0 (C-11), 13.5 (C-24); ESIMS m/z 486 [M+Na] , $949[2 \mathrm{M}+\mathrm{Na}]^{+}$.

Rosellichalasin (4): White amorphous solid; $\mathrm{C}_{28} \mathrm{H}_{33} \mathrm{NO}_{5}$; UV (MeOH) $\lambda_{\max }(\log \varepsilon) 244$ (3.75) nm; ${ }^{13} \mathrm{C}-\mathrm{NMR}\left(\mathrm{CDCl}_{3}\right): \delta 205.4$ (C-17), 171.6 (C-1), 169.0 (C-21), 143.0 (C-18), 136.5 (C-1'), 135.2 (C-14), 131.7 (C-19), 129.5 (C-2' \& 6'), 128.8 (C-3' \& 5'), 127.1 (C-4'), 125.6 (C-13), 84.5 (C-9), 60.1 (C-3), 57.1 (C-6), 53.8 (C-7), 48.9 (C-4), 46.9 (C-8), 44.1 (C-10), 39.7 (C-5), 39.6 (C-15), 36.4 (C-20), 
35.9 (C-16), 19.5 (C-12), 17.3 (C-11), 12.8 (C-23), 12.7 (C-24); ESI-MS m/z 486 [M+Na] , $949[2 \mathrm{M}+\mathrm{Na}]^{+}$.

Cytochalasin $\mathrm{Z17}$ (5): White amorphous solid; $\mathrm{C}_{28} \mathrm{H}_{33} \mathrm{NO}_{5}$; UV (MeOH) $\lambda_{\max }(\log \varepsilon) 242$ (3.71) nm; ${ }^{13} \mathrm{C}-\mathrm{NMR}\left(\mathrm{CDCl}_{3}\right)$ : $\delta 205.5$ (C-17), 171.6 (C-1), 168.9 (C-21), 143.2 (C-18), 137.1 (C-14), 137.0 (C-1'), 132.9 (C-6), 131.5 (C-19), 129.2 (C-2' \& 6'), 128.9 (C-3' \& 5'), 127.1 (C-4'), 126.4 (C-13), 125.1 (C-5), 83.7 (C-9), 69.6 (C-7), 59.2 (C-3), 50.0 (C-8), 49.6 (C-4), 43.7 (C-10), 40.1 (C-16), 39.7 (C-15), 37.4 (C-20), 17.5 (C-11), 17.2 (C-23), 14.1 (C-12), 13.0 (C-24); ESI-MS m/z 486 [M+Na], $949[2 \mathrm{M}+\mathrm{Na}]^{+}$.

Xylapyrone $A$ (6): white amorphous powder; UV (MeOH) $\lambda_{\max }(\log \varepsilon) 201$ (0.16), 280 (2.94) nm; ${ }^{1} \mathrm{H}-\mathrm{NMR}$ (DMSO- $d_{6}$ ) and ${ }^{13} \mathrm{C}-\mathrm{NMR}$ (DMSO- $d_{6}$ ) spectral data see Table 1 . HREIMS $\mathrm{m} / \mathrm{z} 254.1147$ $[\mathrm{M}]^{+}$(calcd for $\left.\mathrm{C}_{13} \mathrm{H}_{18} \mathrm{O}_{5}, 254.1154\right)$.

Xylapyrone $B$ (7): white amorphous powder; UV (MeOH) $\lambda_{\max }(\log \varepsilon) 201(0.14), 280$ (2.93) nm; ${ }^{1} \mathrm{H}-\mathrm{NMR}$ (DMSO- $d_{6}$ ) and ${ }^{13} \mathrm{C}-\mathrm{NMR}$ (DMSO- $d_{6}$ ) spectral data see Table 1 . HREIMS $\mathrm{m} / \mathrm{z} 256.1308$ $[\mathrm{M}]^{+}$(calcd for $\mathrm{C}_{13} \mathrm{H}_{20} \mathrm{O}_{5}, 256.1311$ ).

Xylapyrone $C$ (8): white amorphous powder; UV (MeOH) $\lambda_{\max }(\log \varepsilon) 201$ (0.15), $280(2.93) \mathrm{nm}$; ${ }^{1} \mathrm{H}-\mathrm{NMR}$ (DMSO- $d_{6}$ ) and ${ }^{13} \mathrm{C}-\mathrm{NMR}$ (DMSO-d6) spectral data see Table 1. HREIMS $\mathrm{m} / \mathrm{z} 212.1045$ $[\mathrm{M}]^{+}$(calcd forC ${ }_{11} \mathrm{H}_{16} \mathrm{O}_{4}, 212.1049$ ).

Xylapyrone D (9): white amorphous solid; UV (MeOH) $\lambda_{\max }(\log \varepsilon) 201$ (0.14), 280 (2.98) nm; ${ }^{1} \mathrm{H}-\mathrm{NMR}$ (DMSO-d6) and ${ }^{13} \mathrm{C}-\mathrm{NMR}$ (DMSO-d6) spectral data see Table 2. HREIMS $\mathrm{m} / \mathrm{z} 228.0991$ $[\mathrm{M}]^{+}$(calcd for $\left.\mathrm{C}_{11} \mathrm{H}_{16} \mathrm{O}_{5}, 228.0998\right)$.

Xylapyrone $E$ (10): pale yellow oil; UV (MeOH) $\lambda_{\max }(\log \varepsilon) 201(0.15), 280$ (2.99) nm; ${ }^{1} \mathrm{H}-\mathrm{NMR}$ (DMSO- $d_{6}$ ) and ${ }^{13} \mathrm{C}-\mathrm{NMR}$ (DMSO- $d_{6}$ ) spectral data see Table 2. HREIMS $\mathrm{m} / z$ 198.0886 [M] ${ }^{+}$(calcd for $\mathrm{C}_{10} \mathrm{H}_{14} \mathrm{O}_{4}, 198.0892$ ).

Xylapyrone $F$ (11): white amorphous powder; UV (MeOH) $\lambda_{\max }(\log \varepsilon) 201$ (0.17), 280 (2.99) nm; ${ }^{1} \mathrm{H}-\mathrm{NMR}$ (DMSO- $d_{6}$ ) and ${ }^{13} \mathrm{C}-\mathrm{NMR}$ (DMSO- $d_{6}$ ) spectral data see Table 2. HREIMS $\mathrm{m} / z$ 184.0729 $[\mathrm{M}]^{+}$(calcd for $\mathrm{C}_{9} \mathrm{H}_{12} \mathrm{O}_{4}, 184.0736$ ).

\subsection{Cytotoxicity Test}

The cancer cell lines CaSki and HepG2 were obtained from the Shanghai Institute of Cell Biology, Chinese Academy of Science (Shanghai, China). All cells were maintained in RPMI-1640 medium supplemented with 10\% fetal calf serum, $25 \mathrm{mM}$ HEPES buffer, $2 \mathrm{mmol} / \mathrm{L}$ L-glutamine, $100 \mu \mathrm{g} / \mathrm{mL}$ streptomycin, and $100 \mathrm{U} / \mathrm{mL}$ penicillin. Cultures were incubated in a humidified atmosphere of 5\% $\mathrm{CO}_{2}$ at $37{ }^{\circ} \mathrm{C}$. Cells $\left(1 \times 10^{4} /\right.$ well $)$ were seeded in supplemented culture medium $(100 \mu \mathrm{L} /$ well $)$ in a 96-well plate and incubated for $24 \mathrm{~h}$. The medium was then replaced with a test compound-containing medium, and the cells were further incubated for $48 \mathrm{~h}$. All experiments were run in parallel with controls ( $0.1 \%$ DMSO without test compounds) and the cell viabilities were evaluated by MTT assays. The 
absorbance of formazan formed was measured at $570 \mathrm{~nm}$ by a microplate reader. The concentrations resulting in 50\% inhibition of cell proliferation/survival ( $\left.\mathrm{IC}_{50}\right)$ as measured by this assay are given in Table 3. Each experiment was repeated three times.

\section{Conclusions}

The Xylaria genus is an ubiquitous filamentous fungus, often isolated from marine environments and terrestrial sources, that can produce various types of secondary metabolites, including typical cytochalasins [17], terpenoids [18], benzofurans [19], xanthones [20], and cyclopeptides [21]. Long-chain $\alpha$-pyrones are widespread in Nature and most of the PKS genes have been involved in the biosynthesis of their derivatives from acetate units [22,23]. A few papers have reported $\alpha$-pyrone metabolites from Xylaria sp. Pukachaisirikul et al. described the isolation of one known $\alpha$-pyrone derivative [24]. In this paper, five known cytochalasin-type analogues 1-5 were isolated as the major metabolites from a solid rice medium culture of Xylaria sp. BM9. However, applying liquid culture conditions to Xylaria sp. BM9 resulted in the identification of six new $\alpha$-pyrone derivatives, xylapyrones A-F (compounds 6-11), with different biogenetic origin, in which its PKS genes for the biosynthesis of complex liquids were actived. Xylapyrones A-F were evaluated for in vitro cytotoxicity against two cancer cell lines (Hep-G2 and Caski) and found to be inactive. Further bioassay evaluation of the compounds against fungi and other targets are ongoing, so it is an issue that we don't have sufficient amounts of these compounds to determine the absolute stereochemistry of compounds 6, 7 and 9.

\section{Supplementary Materials}

Supplementary materials can be accessed at: http://www.mdpi.com/1420-3049/20/05/7940/s1.

\section{Acknowledgments}

This work was supported by grants from the National Natural Science Foundation of China (31100080 and 21272136), Science Foundation of China Three Gorges Universtiy (KJ2011B003 and KJ2014B021), Yichang Science Research and Development Project (A13301-56), and The Education Department of Hubei Province Key Project (D20141201).

\section{Author Contributions}

All authors performed the biological and chemical experiments. H. Zhang especially contributed to the isolation of the strain, fermentation, and purification of compounds 1-11. X. Tu finished the identification of fungi Xylaria sp. BM9. Z. Deng and K. Zou managed and supervised the project, elucidated the structure of compounds 1-11 and prepared and corrected the manuscript. Z. Guo and N. Huang recorded and analyzed the NMR data to determine their chemical structures. H. He and Y. Peng evaluated the cytotoxicity of compounds 1-11. Z. Deng wrote the paper. All authors read and approved the final manuscript. 


\section{Conflicts of Interest}

The authors declare no conflict of interest.

\section{References}

1. Cragg, G.M.; Grothaus, P.G.; Newman, D.J. Impact of Natural Products on Developing New Anti-Cancer Agents. Chem. Rev. 2009, 109, 3012-3043.

2. Hertweck, C.; Scherlach, K. Triggering Cryptic Natural Product Biosynthesis in Microorganisms. Org. Biomol. Chem. 2009, 7, 1753-1760.

3. Singh, B.K.; Macdonald, C.A. Drug Discovery from Uncultivable Microorganisms. Drug Discov. Today 2010, 15, 792-799.

4. Yang, X.L.; Zhang, J.Z.; Luo, D.Q. The Taxonomy, Biology and Chemistry of the Fungal Pestalotiopsis genus. Nat. Prod. Rep. 2012, 29, 622-641.

5. Paranagama, P.A.; Wijeratne, E.M.K.; Gunatilake, A.A.L. Uncovering Biosynthetic Potential of Plant-Associated Fungi: Effect of Culture Conditions on Metabolite Production by Paraphaeosphaeria quadriseptata and Chaetomium chiversii. J. Nat. Prod. 2007, 70, 1939-1945.

6. Zhang, H.Q.; Deng, Z.S.; Guo, Z.Y.; Tu, X.; Wang, J.Z.; Zou, K. Pestalafuranones F-J, Five New Furanone Analogues from the Endophytic Fungus Nigrospora sp. BM-2. Molecules 2014, 19, 819-825.

7. Bode, H.B.B.; Walker, M.; Zeeck, A. Structure and Biosynthesis of Mutolide, a Novel Macrolide from a UV Mutant of the Fungus F-24'707. Eur. J. Org. Chem. 2000, 8, 1451-1456.

8. Ola, A.R.B.; Thomy, D.; Lai, D.W.; Brötz-Oesterhelt, H.; Proksch, P. Inducing Secondary Metabolite Production by the Endophytic Fungus Fusarium tricinctum through Coculture with Bacillus subtilis. J. Nat. Prod. 2013, 76, 2094-2099.

9. Udwary, D.W.; Zeiqler, L.; Asolkar, R.N.; Singan, V.; Lapidus, A.; Fenical, W.; Jensen, P.R.; Moore, B.S. Genome Sequencing Reveals Complex Secondary Metabolome in the Marine Actinomycete Salinispora tropica. Proc. Natl. Acad. Sci. USA 2007, 104, 10376-10381.

10. Liu, H.; Gu, Q.Q.; Zhu, W.M.; Cui, C.B.; Fan, G.T.; Fang, Y.C.; Zhu, J.T.; Liu, H.B. 10-Phenyl-[12]-cytochalasins $Z_{7}, Z_{8}$ and $Z_{9}$ from the Marine-Derived Fungus Spicariaelegans. J. Nat. Prod. 2006, 69, 871-875.

11. Zhang, H.W.; Zhang, J.; Hu, S.; Zhang, Z.J.; Zhu, C.J.; Ng, S.W.; Tan, R.X. Ardeemins and Cytochalasins from Aspergillu sterreus Resding in Artemisia annua. Planta Med. 2010, 76, $1616-1621$.

12. Li, H.; Xiao, J.; Gao, Y.Q.; Tang, J.J.; Zhang, A.L.; Gao, J.M. Chaetoglobosins from Chaetomium globosum, an endophytic fungus in Ginkgo biloba, and their phytotoxic and cytotoxic activities. J. Agric. Food Chem. 2014, 62, 3734-3741.

13. McGlacken, G.P.; Fairlamb, I.J.S. 2-Pyrone natural products and mimetics: Isolation, characterization and biological acitivity. Nat. Prod. Rep. 2005, 22, 369-385.

14. Shin, H.J.; Lee, H.-S.; Lee, J.S.; Shin, J.; Lee, M.A.; Lee, H.-S.; Lee, Y.-J.; Yun, J.; Kang, J.S. Violapyrones $\mathrm{H}$ and I, New Cytotoxic Compounds Isolated from Streptomyces sp. Associated with the Marine Starfish Acanthaster planci. Mar. Drugs 2014, 12, 3283-3291. 
15. Liu, D.; Li, X.M.; Meng, L.; Li, C.S.; Gao, S.S.; Shang, Z.; Proksch, P.; Huang, C.G.; Wang, B.G. Nigerapyrones A-H, $\alpha$-Pyrone Derivatives from the Marine Mangrove-Derived Endophytic Fungus Aspergillus niger MA-132. J. Nat. Prod. 2011, 74, 1787-1791.

16. Zhang, J.Y.; Jiang, Y.; Cao, Y.; Liu, J.; Zhang, D.; Chen, X.; Han, L.; Jiang, C.L.; Huang, X.S. Violapyrones A-G, $\alpha$-Pyrone Derivatives from Streptomyces violascens Isolated from Hylobates hoolock Feces. J. Nat. Prod. 2013, 76, 2126-2130.

17. Zhang, Q.; Xiao, J.; Sun, Q.Q.; Qin, J.C.; Pescitelli, G.; Gao, J.M. Characterization of cytochalasins from the endophytic Xylaria sp. and their biological functions. J. Agric. Food Chem. 2014, 62, 10962-10969.

18. Isaka, M.; Srisanoh, U.; Sappan, M.; Kongthong, S.; Srikitikulchai, P. Eremophilane and eudesmane sesquiterpenoids and a pimarane diterpenoid from the wood-decay fungus Xylaria sp. BCC 5484. Phytochem. Lett. 2012, 5, 78-82.

19. Xu, F.; Zhang, Y.; Wang, J.J.; Pang, J.Y.; Huang, C.H.; Wu, X.Y.; She, Z.G.; Vrijmoed, L.L.P.; Jones, E.B.G.; Lin, Y.C. Benzofuran Derivatives from the Mangrove Endophytic Fungus Xylaria sp. (\#2508). J. Nat. Prod. 2008, 71, 1251-1253.

20. Healy, P.C.; Hocking, A.; Tran-Dinh, N.; Pitt, J.I.; Shivas, R.G.; Mitchell, J.K.; Kotiw, M.; Davis, R.A. Xanthones from a microfungus of the genus Xylaria. Phytochemistry 2004, 65, 2373-2378.

21. Wu, W.; Dai, H.Q.; Bao, L.; Ren, B.; Lu, J.C.; Luo, Y.M.; Guo, L.D.; Zhang, L.X.; Liu, H.W. Isolation and Structural Elucidation of Proline-Containing Cyclopentapeptides from an Endolichenic Xylaria sp. J. Nat. Prod. 2011, 74, 1303-1308.

22. Thomas, J.S. The ${ }^{13} \mathrm{C}-\mathrm{NMR}$ spectrum of a pyrone metabolite of aspergillus melleus. Biosynthetic incorporation of singly and doubly labelled $\left[{ }^{13} \mathrm{C}\right]$-acetate. Tetrahedron Lett. 1975, 16, 175-178.

23. Terry, D.C.; Gerald, A.P. Pyrones. VIII. Biosynthetic investigations of the fungal metabolite phacidin. Can. J. Chem. 1982, 60, 133-137.

24. Rukachaisirikul, V.; Khamthong, N.; Sukpondma, Y.; Pakawatchai, C.; Phongpaichit, S.; Sakayaroj, J.; Kirtikara, K. An [11]Cytochalasin Derivative from the Marine-Derived Fungus Xylaria sp. PSU-F100. Chem. Pharm. Bull. 2009, 57, 1409-1411.

Sample Availability: Samples of the compounds are not available from the authors because bioactivity tests of those compounds are going on.

(C) 2015 by the authors; licensee MDPI, Basel, Switzerland. This article is an open access article distributed under the terms and conditions of the Creative Commons Attribution license (http://creativecommons.org/licenses/by/4.0/). 